2010-01-01

\title{
From Federations to Global Factories: Assessing the Contribution of the Subsidiary Middle Manager in Today's MNE
}

Donal O'Brien

Technological University Dublin, donal.obrien@tudublin.ie

Pamela Sharkey Scott

Technological University Dublin, pamela.sharkeyscott@tudublin.ie

Pat Gibbons

University College Dublin, pat.gibbons@ucd.ie

Follow this and additional works at: https://arrow.tudublin.ie/buschmanart

Part of the International Business Commons, and the Strategic Management Policy Commons

\section{Recommended Citation}

O'Brien, D., Sharkey Scott, P., Gibbons, P.: From Federations to Global Factories: Assessing the Contribution of the Subsidiary Middle Manager in Today's MNE. Academy of International Business UKI, Conference Book, Palgrave MacMillan.

This Article is brought to you for free and open access by the School of Management at ARROW@TU Dublin. It has been accepted for inclusion in Articles by an authorized administrator of ARROW@TU Dublin. For more information, please contact arrow.admin@tudublin.ie, aisling.coyne@tudublin.ie,gerard.connolly@tudublin.ie.

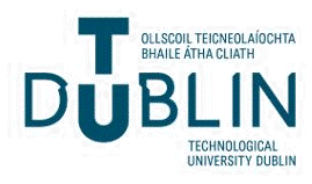




\title{
From Federations to Global Factories; Assessing the contribution of the subsidiary middle manager in today's MNE
}

\begin{abstract}
The evolution of MNEs (Multinational Enterprises) from rigid and hierarchical structures to more distributed authority and autonomy led to the theoretical justification for conceptualising them as a federative rather than unitary organisations (Ghoshal and Bartlett, 1990). Fundamental to the Federative MNE is the suggestion that subsidiary units, through their own actions, can modify the power base and influence MNE strategy 'from below' (Andersson et al., 2007). Considerable research highlights the potential of subsidiary units for knowledge creation and initiative (Birkinshaw, 1997, Rugman and Verbeke, 2001, Williams, 2009), but to date it has failed to confirm that MNEs actually operate as federations.
\end{abstract}

The motivation for the establishment of subsidiaries is changing and there is a need to adopt a new approach to the study of the MNE (Yamin and Sinkovics, 2009). Traditionally the key strategic issue for International business scholars was the handling of tension between the importance of global integration on the one hand and the need for national responsiveness on the other (Bartlett and Ghoshal, 1987). However, the emergence of global demand for products has reduced the need for national responsiveness (Mudambi, 2008). The pattern of FDI is increasingly influenced by the reality that host countries, rather than being markets, instead fit into the strategic calculation of MNEs as sites for key resources and capabilities. Top management of MNEs have become increasingly able to segment their activities and to seek the optimal location for increasingly specialised slivers of activity (Buckley and Ghauri, 2004). This approach of 'fine slicing activities' enables MNEs to amplify their focus on narrower value chain activities associated with the highest value added (Mudambi, 2008). These developments are leading to the potential demise of the Federative MNE (Yamin and Forsgren, 2006) and the arrival of the 'Global Factory' (Buckley, 2009b).

The research objective in this paper is to access the impact MNE structural developments are having on subsidiary strategy development. The actors and practices that contribute to strategy development at the subsidiary level is already a neglected research area (Dörrenbächer and Geppert, 2009). Although the essence of strategy is contributing to competitive advantage through management activities (Papadakis et al, 1998), much of the focus of research up to this point has been on the strategic relationship between subsidiary top management and corporate headquarters (Bouquet and Birkinshaw, 2008). The contribution to strategy development by the middle management levels within subsidiaries has largely been overlooked (Balogun, 2003). Using Floyd and Wooldridge's (1992) model of middle manager strategic influence in organisations, the focus of this paper is to analyse the contribution of subsidiary middle managers and contribute to the underdeveloped literature on subsidiary strategy development, in a time when theory development on the MNE is moving away from the "Federation" towards the "Global Factory". 


\section{From Federations to Global Factories; Assessing the contribution of the subsidiary middle manager in today's MNE}

\section{INTRODUCTION}

The historic literature on the Multinational Enterprise (MNE) concentrated on a hierarchical parent and child relationship between corporate headquarters and their subsidiaries. Classical theories of MNE evolution (Vernon, 1966, Johanson and Vahlne, 1977, Dunning, 1979) outlined subsidiary development as a HQ driven process. The view was taken that strategic thinking emanates from the centre of the organisation and is then implemented by subsidiaries which act as instruments of the parent company's overall strategy (Delany, 2000). An alternative perspective suggests (White and Poynter, 1984, Jarillo and Martinez, 1990, Birkinshaw and Hood, 1998, Rugman and Verbeke, 2001, Williams, 2009) that subsidiaries are far more than simply implementers of their parent companies' will.

Subsidiary units evolve over time and through their own actions and initiatives have the potential to modify the power structures of the MNE and influence strategy 'from below' (Andersson et al., 2007). One outcome of this progression is that MNEs become federative rather than unitary organisations as the structures of power and control become dispersed throughout the MNE (Bartlett and Ghoshal, 1990). The control problem in the federative MNE is the result of the invisibility of subsidiary networks and the resultant knowledge deficit for headquarters. However, recent developments in the field suggest that the federative structure may no longer be relevant. Increased globalisation and improvements in ICT have enabled MNEs to tackle the control problem by dividing the scope of subsidiary activities into significantly smaller pieces (Yamin and Sinkovics, 2009). The result is amplified headquarters control over dispersed value chains, a development which Buckley describes as the emergence of the "Global Factory" (Buckley, 2009b). 
In a federal structure, strategy development at the subsidiary level is a key routine of the subsidiary unit, but as recent literature departs from this on the basis of increased headquarters control over strategy what does this mean for subsidiaries? Subsidiary strategy development, despite its demonstrated importance (Taggart, 1998a, Frost, 2001, Birkinshaw et al., 2005), is an element of the internal functioning of subsidiaries which has remained a neglected research area (Dörrenbächer and Geppert, 2009). Taking Floyd and Wooldridge's model of middle manager strategic influence in organisations as an initial starting point, the objective of the study is, to research the contribution of subsidiary middle managers and contribute to the underdeveloped literature on subsidiary strategy development at a time of change in MNEs.

We present the findings of an in-depth case study exploring the role of subsidiary middle managers in developing strategy within a well established and successful MNE. We firstly contribute by confirming anecdotal evidence that subsidiaries engage in formal strategy development. Secondly the findings show that increased headquarters control over strategy has serious consequences for the overall contribution of the subsidiary middle manager. Besides its potential for theory development, this area is particularly relevant to practitioners on two levels. Firstly, at the subsidiary level the strategic contribution of the middle management levels is vital in protecting the subsidiary's long term position within the MNE. Secondly, subsidiaries are recognised as sources of knowledge that can be diffused and utilised throughout the MNE network (Mudambi, 2008), helping to stimulate the continuous adaption and 'constant reinvention' required to compete in the global environment. Unlocking the potential of the subsidiary middle manager is an essential component to deliver on this promise. 


\section{THEORETICAL FRAMEWORK}

\section{From Federations to Global Factories}

Conceptualising the MNE as a federative rather than a unitary organisation was first proposed by Bartlett and Ghoshal (1990). They contended that in the case of MNEs "fiat" is particularly limited not only because some of the subsidiaries are very distant and resource rich but more so because they control critical linkages with key actors in their local environments. The resulting subsidiary embeddedness has two related consequences with serious implications for the ability of headquarters to retain exclusive control over strategy (Yamin and Sinkovics, 2007).

Firstly embeddedness generates knowledge based resources through subsidiary linkages within networks (Andersson et al., 2002, Forsgren et al., 1999). Such resources are typically outside the control of MNE headquarters and increase a subsidiary's power and hence its scope for independent action and initiatives (Andersson et al., 2002, Birkinshaw and Ridderstråle, 1999, Mudambi and Navarra, 2004). Secondly and perhaps even more importantly, the networks in which the subsidiary is located, are often invisible to corporate headquarters (Holm et al., 1995). As a consequence knowledge deficit is created, and related bounded rationality problems arise for headquarters in terms of the subsidiary's operating environment and resource base (Cantwell and Mudambi, 2005).

Andersson et al (2007) contend that the vital element in the federative model is that it highlights how the subsidiary's own actions can influence the strategy of the MNE 'from below'. Consequently the federative model proposes a landscape where subsidiaries have a number of strategic options to influence their own future and that of the overall MNE. Over the last two decades, resource based theories adopting the federal perspective (Ghoshal and 
Bartlett, 1990) emphasise the role of subsidiary units as knowledge creators supporting the premise that subsidiaries access power and influence within the MNE network e.g. (Birkinshaw, 1997, Delany, 2000, Bouquet and Birkinshaw, 2008a). But in that time the evidence of MNEs actually operating as federations, as a result of a substantial number of subsidiaries gaining significant influence with the MNE, has been unclear. In fact recent literature suggests a retreat from the federative structure as MNE top management, enabled by changes in structure and developments in ICT, have begun dealing with the question of control over strategy in the MNE. The overall consideration determining the extent of multinationality remains the retention of control over corporate strategy by headquarters (Hymer, 1970)

The root of the control problem in the federative structure is the invisibility of subsidiary networks and the resultant knowledge deficit for the headquarters. However, although MNE headquarters may experience a limit to their power in controlling distant subsidiaries, they retain the power to structure the corporation in suitable ways to reduce its federative character (Yamin and Forsgren, 2006). There is evidence of this power in two important structural developments, which may herald the 'demise of the federative MNE' (Yamin and Sinkovics 2007 p.326).

Firstly, subsidiary value chain scope is being dramatically reduced, driven by MNE top management's increased control, over their network of subsidiaries. In the federative MNE, national subsidiaries play an important role in the organisation. National responsiveness is widely regarded as a vital requirement for competitive advantage. This involves subsidiaries developing the local knowledge and organisational capabilities to coordinate a number of value added activities to serve local demands effectively. But the national subsidiary is 
becoming an 'endangered species' (Birkinshaw, 2001). In the place of a national subsidiary, there is a series of discreet value added activities, each of which reports through its own business unit or functional line. Buckley and Ghauri (2004) observed a similar phenomenon and contend that MNE strategies now revolve around the disintegration of the value chain. The managers of MNEs are increasingly able to segment their activities and to seek the optimal location for increasingly specialised slivers of activity (Buckley and Ghauri, 2004, p.83). Mudambi (2008) refers to this approach as 'fine slicing'. This process enables firms to amplify their focus on narrower activities within the value chain associated with the highest value added. (Mudambi, 2008).

The second structural development comprises increased offshoring and outsourcing of core activities. The relevance of outsourcing to the demise of the federative structure is that, through outsourcing, the MNE centre shifts from invisible networks around subsidiaries to visible networks controlled by the centre itself. As a result externalisation actually helps shift the balance of power in favour of control and planning by the MNE centre (Nolan et al., 2002, Strange and Newton, 2006).

The motivation for the establishment of subsidiaries has changed and therefore there is a need to adopt a new approach to the study of the MNE. Traditionally International business scholars assumed that the key strategic issue for the MNE was the handling of the tension between the imperative of global integration on the one hand and the need for national responsiveness on the other (Bartlett and Ghoshal, 1987). The need for responsiveness, in part, reflected an environment in which national governments had significantly more bargaining power in their dealings with MNEs than they generally do today. Globalisation has reduced the need for national responsiveness. Overall MNE strategies are moving towards 
greater global, or at least regional, integration and their investment decisions are increasingly motivated by efficiency and strategic asset seeking. The growing liberalisation of markets and greater mobility of firm specific assets have become key influences on MNE strategies (Dunning, 2000, Dunning, 2002, Dunning and Narula, 2004). The pattern of FDI flow is increasingly influenced by the reality that host countries fit into the strategic calculation of MNEs as sites for key resources or capabilities rather than markets. The more precise use of locational and ownership strategies by MNEs is the very essence of increasing globalisation. Rather than federations, MNEs are now developing into what Buckley has labelled the 'global factory’ (Buckley, 2009a).

Global factories arise due to the MNE's evolution into differentiated networks which only internalise those activities which it cannot more profitably outsource (Buckley and Ghauri, 2004). MNEs have developed the ability to 'fine slice' their activities on an even more precise calculus. As a result they are increasingly able to alter location and internalise decisions for activities which were previously locationally bound by being tied to other activities. Subsidiary embeddedness in networks is reduced and control predominantly resides at the top of the organisation (Buckley, 2009a).

The notion of MNEs as global factory requires a rethink of the role of the subsidiary within the MNE. The global factory has arrived and theory needs to reflect the changing role of the subsidiary. From the subsidiary perspective there is an important contribution to be made in studying the consequences of these recent developments on the internal functioning of the subsidiary. Taking the subsidiary middle manager as the unit of analysis this paper focuses on their input to subsidiary strategy development and how recent changes in the structure of the MNE are impacting on this role. 


\section{$\underline{\text { Subsidiary Strategy Development }}$}

Historically, the unit of analysis was the firm with the role of subsidiaries in strategy development largely overlooked. However, the modern multinational subsidiary is now conceptualised as competing in a complex competitive arena, an internal environment of other subsidiaries, internal customers and suppliers and an external environment consisting of customers suppliers and competitors (Birkinshaw et al., 2005). This suggests that subsidiaries must develop different strategies to cope with the particular market in which they compete, but little research has been carried out on what strategy development takes place and who contributes to strategy development within the subsidiary (Dörrenbächer and Gammelgaard, 2006, Dörrenbächer and Geppert, 2009).

In previous research middle level managers have not been considered part of the strategy development process except as providers of informational inputs and directors of implementation (Floyd and Woolridge, 1997). However, contemporary theory suggests that middle managers attempt to influence the strategy development process (Hornsby et al., 2002), and that given their contribution in other areas of the organisation, their potential role in this process should not be overlooked. As top management teams struggle to cope with increasingly complex and dispersed organisations (Wooldridge et al., 2008), strategic activity and decision making has become more dispersed throughout the organisation (Balogun and Johnson, 2004). Thus, the role of the middle manager in strategy development has become an important area of research.

Middle managers hold a unique position within the organisation. The description of the 'linking' pin by Likert (1961) is used to define this unique position. Here, a superior in one group is a subordinate in the next, and so on throughout the organisation. This is particularly 
relevant to MNEs where there may be numerous levels of management throughout the organisation. As participants in multiple, vertically related groups, middle managers coordinate top and operating level activities, and they are involved in processes that have both upward and downward influences on strategy formulation

\section{RESEARCH QUESTION}

If the federal structure exists, and subsidiaries develop their own strategy and influence MNE strategy 'from below', what is the role of the subsidiary middle manager in this process? However, if recent trends in literature are correct, suggesting a retreat from federal structures towards Global factories, how does this affect the strategic contribution of subsidiary middle managers? These questions will be addressed in the discussion section of the paper.

\section{METHODOLOGY}

\section{$\underline{\text { Research Design }}$}

The complex activities of middle managers in developing strategy were explored through a case study research design (Yin, 2003, Eisenhardt, 1989). Case studies are particularly appropriate when 'the phenomenon under study is not readily distinguishable from its context' (Yin, 2003, p. 4). This is certainly the situation when studying subsidiary middle managers whose contribution to strategy development is often tied up in their daily interactions within different levels of the organisation (Wooldridge et al., 2008). However, there are difficulties in writing a paper based on case research. Firstly there is the charge of having too small a sample, and secondly there is the problem of nonrepresentativeness. Despite these difficulties Siggelkow (2007) proposes three important uses for case research: motivation, inspiration and illustration. In this paper the choice of case based research is predominantly to motivate further research in a relatively under developed area. By grounding the study in a real life 
situation it is far more likely to promote discussion and the conceptual contribution put forward in the paper will be a great deal more relevant.

\section{$\underline{\text { Selecting the Case }}$}

Similar to other investigations of the role of middle managers in organizations (Balogun and Johnson, 2004, Balogun and Johnson, 2005, Huy, 2002, Rouleau, 2005), we present the results of a study of a single organisation. This organisation was specifically selected to represent a mature and well established provider of pharmaceutical products, operating within a relatively stable environment. The chosen setting is a world leading health care MNE (Alpha) with its headquarters in the United States and operations in more than 130 countries. The company is a broad based health care company and has sales, manufacturing, research and development and distribution facilities around the world. The company's Irish operation was selected for this study as it consists of 4 different subsidiaries, each with their individual history of existence in Ireland and with very specific mandates in either, pharmaceuticals, nutrition, diagnostics or medical products. These subsidiaries provided a context in which a variety of types, levels, and methods of strategy development could be observed. Its strong market position has supported the development of a range of innovative products and strategies (as appropriate to describe Alpha), but costs have recently become a primary consideration and several of the local activities have been outsourced. One of the reasons which supported Alpha's selection is its reputation for building subsidiary networks and encouraging subsidiary development.

\section{Data Collection}

Initial analysis was carried out in a review of the company web site, annual reports and press releases. Then semi structured interviews of approx one hour were organised with 12 middle 
managers across the four subsidiaries. The middle managers were identified as middle managers by the General Manager of each subsidiary. The results were recorded and transcribed, contact summary sheets were drawn up summarising main themes and recording initial impressions or interesting ideas (Miles and Huberman, 1994). Semi structured interviews were chosen as the most appropriate collection tool to assess the opinions of middle managers on this process. The interview questions focused on how managers interacted with different levels of the organisation in the strategy development process. Similar studies such as Birkinshaw (1997) which looked at the phenomenon of strategy development at the subsidiary level had also used this method of semi structured interviews. For the middle manager perspective there was an emphasis on identifying middle managers with a clear understanding of the company's strategies. In a similar study of this phenomenon Floyd and Wooldridge (1997) employed an operational definition of middle managers, which was provided by Pugh et al (1968); "Middle managers are organisation members who link the activities of vertically related groups and who are responsible for at least sub-functional work flow, but not the work flow of the whole organisation". This definition of middle managers is also employed in this research.

\section{$\underline{\text { Data Analysis }}$}

Given the exploratory nature of the research NVIVO proved crucial in developing a rich and insightful case study. The data collected from the semi structured interviews included a wide range of information on middle manager roles, interactions and strategic functions. Coding the data in NVIVO enabled cross case analysis between the subsidiaries which contextualised the findings and provided a more in depth analysis. 


\section{FINDINGS}

\section{$\underline{\text { Subsidiary Strategy Development }}$}

To analyse subsidiary strategy development the research set out to examine which of the two perspectives of subsidiary strategy development set out by Birkinshaw (1997), best described strategy development in each of the subsidiaries. The first perspective focuses on subsidiaries that are given a mandated strategic role by their parent company. The second perspective is based on subsidiaries with the competencies to develop strategy at the subsidiary management level. Birkinshaw (1997) suggested that the subsidiary mandated role perspective favoured corporate headquarters control, while the subsidiary strategy development perspective favoured higher levels of subsidiary influence. The primary research collected in this study tended to support the first of the perspectives identified by Birkinshaw (1997). In all of the subsidiaries, strategic goals and objectives are set by the parent company and although subsidiary management have certain influence within their mandate, the overall theme from the interviewees was that strategy is developed at corporate headquarters and passed down to the subsidiaries. One of the interviewees from Site D commented that

"we have very little visibility of the strategy which is developed at the corporate level; our main strategic input is to take the strategy given to us by corporate headquarters and break it down into achievable goals for the subsidiary".

\section{$\underline{\text { Subsidiary Middle Management's Strategic Contribution }}$}

The findings sought to explore the contribution of subsidiary middle managers to strategy development, by considering the emergence of an updated model based on Floyd and Wooldridge's (1992).(Fig.1) original typology. Based on the premise of upward and downward influences of middle managers it provides a framework on which to study the strategic contribution of subsidiary middle managers. From a review of the literature on 
strategy development, and more specifically subsidiary strategy development, additional strategic roles were also highlighted (Fig. 2) for their potential significance in an updated model. It was expected that a number of these roles would emerge specific to the subsidiary middle manager.

\begin{tabular}{|c|c|}
\hline Upward Influence & Downward Influence \\
\hline $\begin{array}{l}\text { Championing } \\
\text { Alternatives }\end{array}$ & $\begin{array}{l}\text { Facillitating } \\
\text { Adaptability }\end{array}$ \\
\hline $\begin{array}{l}\text { Synthesizing } \\
\text { Information }\end{array}$ & $\begin{array}{l}\text { Implementing } \\
\text { Deliberate Strategy }\end{array}$ \\
\hline
\end{tabular}

Figure 1.

Floyd and Wooldridge (1992) Typology of Middle Management Involvement in Strategy

Upward Influence

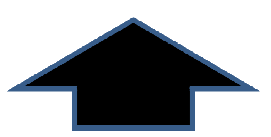

- Transactive

- Autonomy / Control

- Entrepreneur
Downward Influence

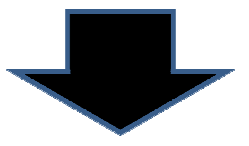

- Incremental Processes

Figure 2.

Proposed Extensions to the Floyd \& Wooldridge (1992) Typology 


\section{$\underline{\text { Middle Manager Strategic Influences (Floyd and Wooldridge 1992) }}$}

\section{Upward Influences}

\section{- Championing Alternatives}

From the primary research collected there is limited evidence of this process taking place within the subsidiaries. In Site A one of the interviewees contended that it was expected within the organisation, that middle management must

"be innovative and identify possible opportunities for the subsidiary".

The interviewee from Site $\mathrm{C}$ also proposed that

"middle managers always have the opportunity to bring their ideas to higher management"

but he could not cite any examples of this process taking place. Although the process of championing alternatives was evident from some interviews all of the interviewees emphasised that their overall strategic goals were always set out by corporate headquarters. Middle management would only suggest an alternative if it was going to aid the subsidiary in the accomplishment of headquarters goals. As one interviewee in Site D put it

“our strategic goals are always based on cost effectiveness and quality as set by HQ. Our strategic inputs are limited to finding new ways to reduce costs or to improve quality”.

In summary only 3 of the 12 interviewees identified strongly with this strategic influence, overall there was a lack of conclusive evidence of it taking place.

\section{- Synthesizing Information}

There was evidence of this strategic role taking place at varying degrees within the subsidiaries. Each interviewee confirmed that top management relied on them for information on the internal processes and external processes of which they had particular knowledge. For example, in Site B one middle manager explained that

"due to the rapid change of technology and business processes in their business sector top management were very reliant on the information they received from the middle manager level". 
The interviewees contended that the knowledge which staff holds, in a highly technical business sector such as healthcare development, is vital to organisations, and therefore how staff presents it to top management can shape the strategy process. However, all of the interviewees identified some frustration in their lack of input in this process and they could not cite any examples of how, through synthesizing information, they had been able to influence strategy 'from below' (Andersson et al., 2007).

\section{Downward Influences}

\section{- Facilitating Adaptability}

The evidence collected in the research suggested that middle managers believed that facilitating learning was a strategic role for middle managers. In the healthcare sector knowledge is a prime asset and as technology and products change so rapidly facilitating learning is a vital function within all of the companies. An interviewee in Site B proposed that "technology is changing and new products are being developed so rapidly that if staff are not working with the new technologies for even a short period of time their knowledge becomes redundant". This was a common theme in all of the interviews.

\section{- Implementing Deliberate Strategy}

In all four subsidiaries the interviewees identified their role in implementing strategy as one of their most important strategic roles. For example in Site $C$ one interviewee stated that

"in their day to day work, middle managers influence strategy by passing it down through the

$$
\text { organisation". }
$$

An interviewee from Site C described the most important strategic role of middle managers, as the process of breaking down strategy from top level strategy into day to day work. In Site D one interviewee stated that the main strategic input of middle managers was 
The evidence collected from the primary research confirmed the importance of this strategic role as proposed by Floyd and Wooldridge (1992) and it emerged as the most identifiable strategic influence of middle managers in the subsidiaries.

\section{Proposed Extensions to the Floyd \& Woodridge's (1992) Typology}

\section{Upward Influences}

\section{- Transactive}

Partial evidence of the importance of a transactive mode, between middle management and higher management levels, proposed by Hart (1992), was apparent in a number of the subsidiaries. The interviewees identified the relationship between top management and middle management as having an influence on strategy development. One of the middle managers from Site A commented that

"as the personal relationship between top management and middle managers developed over time, so too did the input of middle management to strategy development".

Interviewees also noted that subsidiary top management placed a lot of importance on building a culture of personal interaction between management levels. In some cases the middle managers suggested their only chance of exerting an upward strategic influence was based on the personal relationship they had built up with higher level management.

\section{- Autonomy / Control}

For middle managers to contribute to strategy it is accepted that there is a certain level of autonomy required to allow this process to take place (Burgelman, 1983a). The middle managers identified a certain level of autonomy in their day to day activities but, a majority of interviewees contended that overall they were constrained by low levels of autonomy within 
the subsidiary. An interviewee in Site D compared the subsidiary to a previous place of employment and commented that

"I worked in a company which gave high levels of autonomy to management levels within the company, but it is difficult to see that situation arising here to the same degree, as corporate headquarters will always favour a control relationship over the subsidiary rather than allowing higher levels of autonomy to management levels within the subsidiary."

\section{- Middle Manager Entrepreneur}

There was little evidence of this role for middle managers proposed by Birkinshaw (1997). The interviewees did not see themselves as entrepreneurs. One of the interviewees in Site B thought that

"over time this role may emerge but it was difficult to see it developing at the moment".

Interestingly the theme from the interviewees was that they did not identify entrepreneurial skills as a key competence for a middle manager.

\section{Downward Influences}

\section{- Incremental Processes}

There is evidence of this incremental dimension in the results of the primary research. Proposed by Bailey et al (2000), this mode highlights how the uncertainty of the environment means middle manager must be constantly evaluating changes and opportunities in the environment. In all of the interviews there was evidence to show that middle managers believed that building their competencies and being vigilant to the changes in technology were important functions of their role. For example, one of the interviewees in Site D believed that he had very little strategic influence on top management but he proposed that building his own competencies and those of the staff around him was one of the important 
factors driving strategy in the organisation. Similarly, one interviewee in Site B contended that

"strategy could emerge from the skills and knowledge which were developed at the lower levels of the company”.

\section{$\underline{\text { Summary }}$}

To summarise the findings the evidence suggests that while the subsidiaries do engage in strategy development the contribution of the middle manager to this process is predominantly in implementation. This is highlighted by the strong evidence for the downward strategic influences proposed in the original typology, but the limited evidence for the existence of the upward strategic influences of middle managers. This was also confirmed by findings for the proposed extensions to the updated typology.

\section{DISCUSSION}

Subsidiary Strategy Development has been a neglected research area which this paper sought to address (Dörrenbächer and Geppert, 2009). The objective of the findings was to confirm that subsidiaries engage in strategy development and to study middle manager's perception of their role in this process. Although a key task of middle managers is implementing strategy, little research has examined the particular roles they play in this process and how their contribution is captured in formal and informal methods of strategy development (Balogun, 2003).

The findings confirmed that subsidiaries do engage in strategy development but subsidiary managements influence in this process is limited. What emerged from this case, was that strategy predominantly flows from headquarters down through the subsidiary rather than subsidiaries influencing strategy 'from below' as the federative structure suggests (Andersson 
et al., 2007). This was highlighted by the central theme of the model (Floyd and Woolridge, 1992) employed in this study, the distinction between middle manager upstream and downstream strategic influences. From the research carried out there was very strong evidence of the downstream influences. All of the interviewees saw a major strategic role in their day to day activities. Implementing deliberate strategy and facilitating adaptability were strategic roles which all of the interviewees identified. There was also evidence of the incremental planning outlined by Bailey et al (2000), and integrated into the model. Overall middle managers in the subsidiaries strongly identified with downward strategic influences.

However, the evidence for the upward influences was considerably less clear. There was limited evidence for the role of "championing alternatives", and for the proposed extension of a"transactive role", but overall the results showed a lack of evidence for the upward strategic influences of middle management. The levels of autonomy within the subsidiaries were low and middle management identified a high degree of headquarters control. One of the most striking examples of the lack of upward influence was the complete lack of evidence for the entrepreneurial role of subsidiary middle managers, which Birkinshaw (1995a) identified as being an important source of value creation for the MNE.

The data from the four subsidiaries shows very little confirmation for the federative structure proposed by Ghoshal and Bartlett (1990) and highlighted more recently by Andersson et al (2007). An important element of the federative structure is the subsidiaries' ability to influence the MNE 'from below' (Andersson et al., 2007). The interviewees did not express the opinion that subsidiary management had such power within the network. Instead, headquarters control over subsidiary activities was one of the outstanding themes in the interviews. The interviewees highlighted the pressure they were under to meet headquarters 
targets, but they could not see many options in trying the change the power balance. Their main focus was on fulfilling their role as set by headquarters and not jeopardising their position within the MNE.

The feedback from the interviewees suggests that the subsidiaries are more closely aligned to the 'Global Factory' concept proposed by Buckley $(2004$, , 2009b). The subsidiaries fulfil very particular roles within dispersed value chains throughout the world. A number of the interviewees expressed the opinion that their main strategic input was to constantly improve on costs and efficiency. Outside of that they had very little input to strategy development. This was reflected in the strong evidence of middle manager's downward influences keeping the strategic goals set by headquarters "cascading down" through the subsidiary. Control over strategy resides at headquarters and subsidiary middle management's contribution to strategy is predominantly in implementation.

\section{$\underline{\text { Implications }}$}

Organisations have become increasingly aware that middle managers play a pivotal role in developing new ideas, reshaping firm capabilities and affecting strategic renewal (Pappas and Wooldridge, 2007), but is this evident in today's MNEs? Not so long ago the MNE was being held up as an organisation with a particular competence for knowledge creation due to the potential within its network of diverse subsidiaries. But, as the global factory emerges resulting in knowledge and innovation being created in smaller pockets of the MNE what does the future hold for the subsidiary middle manager? Are they destined to be implementers rather than creators? 


\section{$\underline{\text { Limitations of the Study }}$}

Like all studies, the one presented here suffers from a number of important limitations that must be kept in mind when interpreting the results. The preliminary nature of the study led to a number of important restrictions. This particular study used a small number of subsidiaries in one case organisation in a limited geographical area. Hence, there is a need to conduct extensive research across different industries and geographical regions before any generalisations can be drawn. Additionally, the research used only a qualitative approach to collect data; a study employing both qualitative and quantitative approaches would provide a more in depth analysis on this particular topic.

\section{Other Areas for Future Research}

The findings from this study represent an exciting and valuable contribution to our knowledge of an under researched area i.e. the strategic roles of middle managers in the strategy development process of multinational subsidiaries. One of the major contributions of an exploratory study of this kind is to highlight opportunities for further research. In particular, the proposed extensions to the model outlined in the study would benefit from longitudinal analysis. To seek further justification of the validity of this model a more thorough research process should be undertaken. 


\section{REFERENCES}

ANDERSSON, Ulf., FORSGREN, Mats. \& HOLM, Ulf. (2002) The Strategic Impact of External Networks: Subsidiary Performance and Competence Development in the Multinational Corporation. Strategic Management Journal, 23, 979-996.

ANDERSSON, Ulf., FORSGREN, Mats. \& HOLM, Ulf. (2007) Balancing subsidiary influence in the federative MNC: a business network view. Journal of International Business Studies, 38, 802-818. BALOGUN, Julia. (2003) From Blaming the Middle to Harnessing its Potential: Creating Change Intermediaries. British Journal of Management, 14, 69-83.

BALOGUN, Julia. \& JOHNSON, Gerry. (2004) Organizational Restructuring and Middle Manager Sensemaking. Academy of Management Journal, 47, 523-549.

BALOGUN, Julia. \& JOHNSON, Gerry. (2005) From Intended Strategies to Unintended Outcomes: The Impact of Change Recipient Sensemaking. Organization Studies (01708406), 26, 1573-1601. BARTLETT, Christopher. \& GHOSHAL, Sumantra. (1990) The Multinational Corporation as an Interorganisational Network. Academy of Management Review, 15, 603-625.

BARTLETT, Christopher. A. \& GHOSHAL, Sumantra. (1987) Managing across borders: New strategic requirements. Sloan Management Review, 28, 7-17.

BIRKINSHAW, Julian. (1995a) Encouraging Entrepreneurial Activity in Multinational Corporations. Business Horizons, May-June, 32-38.

BIRKINSHAW, Julian. (1997) Entrepreneurship in Multinational Corporations: The Characteristics of Subsidiary Initiatives. Strategic Management Journal, 18, 207-229.

BIRKINSHAW, Julian. (2001) Strategy and management in MNE subsidiaries. IN RUGMAN, Alan. \& BREWER, Thomas. L. (Eds.) The Oxford Handbook of International Business. New York, Oxford University Press.

BIRKINSHAW, Julian. \& HOOD, Neil. (1998) Multinational Subsidiary Evolution: Capability and Charter Change in Foreign-Owned Subsidiary Companies. Academy of Management Review, 23, 773795.

BIRKINSHAW, Julian., HOOD, Neil. \& YOUNG, Stephen. (2005) Subsidiary entrepreneurship, internal and external competitive forces, and subsidiary performance. International Business Review, $14,227-248$.

BIRKINSHAW, Julain. \& RIDDERSTRÅLE, Jonas. (1999) Fighting the corporate immune system: a process study of subsidiary initiatives in multinational corporations. International Business Review, 8, 149-180.

BOUQUET, Cyril. \& BIRKINSHAW, Julian. (2008a) Weight Versus Voice: How Foreign Subsidiaries Gain Attention From Corporate Headquarters. Academy of Management Journal, 51, 577 601. 
BUCKLEY, Peter. J. (2004) Government policy responses to strategic rent seeking transnational firms. Transnational Corporations, 5, 1-17.

BUCKLEY, Peter. J. (2009a) The impact of the global factory on economic development. Journal of World Business, 44, 131-143.

BUCKLEY, Peter. J. (2009b) Internalisation thinking: From the multinational enterprise to the global factory. International Business Review, 18, 224-235.

BUCKLEY, Peter. J. \& GHAURI, Pervez. N. (2004) Globalisation, economic geography and the strategy of multinational enterprises. Journal of International Business Studies, 35, 81-98.

BURGELMAN, Robert. A. (1983a) A model of interaction of strategic behaviour, corporate context, and the concept of strategy. Academy of Management Review, 8, 61-70.

CANTWELL, John. \& MUDAMBI, Ram. (2005) MNE Competence Creating Subsidiary Mandates. Strategic Management Journal, 26, 1109-1128.

DELANY, Ed. (2000) Strategic Development of the Multinational Subsidiary through Subsidiary Initiative-taking. Long Range Planning, 33, 220-244.

DÖRRENBÄCHER, Christop. \& GAMMELGAARD, Jens. (2006) Subsidiary role development: The effect of micro-political headquarters-subsidiary negotiations on the product, market and value-added scope of foreign-owned subsidiaries. Journal of International Management, 12, 266-283.

DÖRRENBÄCHER, Christoph. \& GEPPERT, Mike. (2009) A micro-political perspective on subsidiary initiative-taking: Evidence from German-owned subsidiaries in France. European Management Journal, 27, 100-112.

DUNNING, John., H. (1979) Explaining Changing Patterns of International Production: In Defence of the Eclectic Theory. Oxford Bulletin of Economics and Statistics, 41, 269-295.

DUNNING, John., H. (2000) The eclectic paradigm as an envelope for economic and business theories of MNE activity. International Business Review, 9, 163-190.

DUNNING, John., H. (2002) Regions, globalization, and the knowledge-based economy, Oxford, Oxford University Press.

DUNNING, John., H. \& NARULA, Rajneesh. (2004) Multinationals and industrial competitiveness: A new agenda, Cheltenham, Edward Elgar.

EISENHARDT, Kathleen. M. (1989) Building theory from case study research. Academy of Management Review, 14, 532-50.

FLOYD, Steven. W. \& WOOLRIDGE, Bill. (1992) Middle Management Involvement in Strategy and its Association with Strategic Type. Strategic Management Journal, 13, 53-168.

FLOYD, Steven. W. \& WOOLRIDGE, Bill. (1997) Middle Managements Strategic Influence and Organisational Performance. Journal of Management Studies, 34, 465-485.

FORSGREN, Mats., PEDERSEN, Torben. \& FOSS, Nicolai. J. (1999) Accounting for the strenghts of MNC subsidiaries: the case of foreign owned firms in Denmark. International Business Review, 8, 191-196. 
FROST, Tony. S. (2001) The Geographic Sources of Foreign Subsidiaries' Innovations. Strategic Management Journal, 22, 101-123.

GHOSHAL, Sumantra. \& BARTLETT, Christopher. A. (1990) The Multinational Corporation as an Interorganizational Network. Academy of Management Review, 15, 626-625.

HART, Stuart. (1992) An Integrated Framework for Strategy Making Processes. Academy of Management Review, 17, 327-351.

HOLM, Ulf., JOHANSON, Jan. \& THILENIUS, Peter. (1995) Headquarters knowledge of subsidiary network contexts in the multinational corporation. International Studies of Management \& Organization, 2, 97-120.

HORNSBY, Jeffrey. S., KURATKO, Donald. F. \& SHAKER, Zahra. A. (2002) Middle Managers' Perception of the Internal Environment for Corporate Entrepreneurship: assessing the measurement scale. Journal of Business Venturing, 17, 253-273.

HUY, Quy. Nguyen. (2002) Emotional Balancing of Organizational Continuity and Radical Change: The Contribution of Middle Managers. Administrative Science Quarterly, 47, 31-69.

HYMER, Stephen. H. (1970) The efficiency (contradictions) of multinational corporations. The American Economic Review: Papers and Proceedings, 60, 441-448.

JARILLO, J. Carlos. \& MARTINEZ, Jon. L. (1990) Different Roles for Subsidiaries: The Case of Multinational Corporations in Spain. Strategic Management Journal, 11, 501-512.

JOHANSON, Jan. \& VAHLNE, Jan. Erik. (1977) The internationalization process of the firm, a model of knowledge development and increasing foreign market commitments. Journal of International Business Studies, 8, 23-32.

LIKERT, Rensis. (1961) New Patterns of Management, New York, McGraw Hill.

MILES, Mathew. B. \& HUBERMAN, Michael. A. (1994) Qualitative data analysis: an expanded sourcebook, London, Sage.

MUDAMBI, Ram. (2008) Location, control and innovation in knowledge intensive industries. Journal of Economic Geography, 8, 699-725.

MUDAMBI, Ram. \& NAVARRA, Pietro. (2004) Is knowledge power? Knowledge flows, subsidiary power and rent-seeking within MNCs. Journal of International Business Studies, 35, 385-406.

NOLAN, Peter., SUTHERLAND, Dylan. \& ZHANG, Jin. (2002) The challenge of the global business revolution. Contributions to Political Economy, 21, 91-110.

PAPPAS, James. M. \& WOOLDRIDGE, Bill. (2007) Middle Managers' Divergent Strategic Activity: An Investigation of Multiple Measures of Network Centrality. Journal of Management Studies, 44, 323-341.

PUGH, Derek. S., HICKSON, David. J., HININGS, D. R. \& TURNER, C. (1968) Dimensions of Organisational Structure. Administrative Science Quarterly, 13, 65-91.

ROULEAU, Linda. (2005) Micro-Practices of Strategic Sensemaking and Sensegiving: How Middle Managers Interpret and Sell Change Every Day. Journal of Management Studies, 42, 1413-1441. 
RUGMAN, Alan. M. \& VERBEKE, Alain. (2001) Subsidiary Specific Advantages in Multinational Enterprises. Strategic Management Journal, 22, 237-250.

SIGGELKOW, Nicolaj. (2007) PERSUASION WITH CASE STUDIES. Academy of Management Journal, 50, 20-24.

STRANGE, Roger. \& NEWTON, James. (2006) Stephen Hymer and the externalization of production. International Business Review, 15, 180-193.

TAGGART, James. H. (1998a) Strategy Shifts in Multinational Subsidiaires. Strategic Management Journal, 19, 663-681.

VERNON, Raymond. (1966) International Investment and International Trade in the Product Cycle. Quarterly Journal of Economics, 80, 190-207.

WHITE, Rod. E. \& POYNTER, Thomas. A. (1984) Strategies for foreign-owned subsidiaries in Canada. Business Quarterly, Summer, 59-69.

WILLIAMS, Christopher. (2009) Subsidiary-level determinants of global initiatives in multinational corporations. Journal of International Management, 15, 92-104.

WOOLDRIDGE, Bill., FLOYD, Steven. W. \& SCHMID, Torsten. (2008) A Middle-Manager

Perspective: Current Contributions, Sythesis and Future Research. Journal of Management, 34, 11901221.

YAMIN, Mohammed. \& FORSGREN, Mats. (2006) Hymer's analysis of the multinational organization: Power retention and the demise of the federative MNE. International Business Review, $15,166-179$.

YAMIN, Mohammed. \& SINKOVICS, Rudolf. R. (2007) ICT and the MNE reorganisation: the paradox of control. Critical Perspectives on International Business, 3, 322-336.

YAMIN, Mohammed. \& SINKOVICS, Rudolf. R. (2009) Infrastructure or foreign direct investment?: An examination of the implications of MNE strategy for economic development. Journal of World Business, 44, 144-157.

YIN, Robert. K. (2003) Case study research: design and methods London Sage 